\title{
CS Research Square \\ Anticancer activity of food grade nanoemulsions on hepatic cancer cells: a comparative study
}

\section{Sayyeda Hira Hassan}

University of the Punjab

Muhammad Rehan Khan ( $\nabla$ rehankhan@fccollege.edu.pk)

Forman Christian College

\section{Research Article}

Keywords: anticancer activity; nanoemulsions; MMT assay; HepG2 cells

Posted Date: August 20th, 2020

DOI: https://doi.org/10.21203/rs.3.rs-61937/v1

License: (c) (1) This work is licensed under a Creative Commons Attribution 4.0 International License. Read Full License 


\section{Abstract}

The current study was aimed to prepare stable NEs from plant oils to evaluate their cytotoxic effect on HepG2 cells. Oils form three different samples (flax seeds, cloves and olives) were extracted. NEs from these oils were prepared separately by ultrasonication method. After characterization of stable NEs, they were evaluated for their antioxidant and anticancer activities. Extracted oils and their NEs were applied separately to HepG2 cell line to construct a comparison and MTT assay was used for this purpose. Prepared NEs were found more effective against cancer cell line as compared to their respective oils. MTT assay showed efficacy of NEs in reducing cell viability with IC50 value of $10 \mu$ l (flax seed oil), $25 \mu \mathrm{l}$ (clove oil NE) and $1 \mu \mathrm{l}$ (olive oil NE), and was safe to normal cells. The results of the current study revealed that NEs prepared from flax seed, clove and olive oil have the potential for further development as anticancer agents.

\section{Introduction}

From several decades, cancer therapy has been an issue worldwide. Developed drugs to treat cancer are not always successful due to unspecified toxicity, low solubility and multidrug resistance (Sánchez-López et al. 2019). Liver cancer, with less than $9 \%$ five year survival worldwide, is mainly treated by chemotherapy. Chemotherapy enhances the chances of liver peroxidation and lead to miss functioned hepatocytes (Javanshir et al. 2020). Chemotherapeutic drugs cannot differentiate between normal and cancerous cells, thus killing all rapidly normal dividing cells, thus killing all rapidly dividing cells such as gut epithelia, hair follicles, red blood cells and lymphatic cells, making them inadmissible for long term treatment. This poor selectivity of the chemotherapy drugs can lead to damage to surrounding normal growing cells, making them inadmissible for long term treatment. This poor selectivity of the chemotherapy drugs can lead to damage to surrounding normal growing cells (Mahato 2017). Therefore, it is required to discover safe as well as efficient therapeutic tools to aide undesirable side effects in human liver cancer therapy. In this regard, natural products have been proved as successful resource of potential pharmaceutical agent (Esmail et al. 2019). Natural products, especially derived from plants, are found to be effective in cancer chemoprevention and therapy (Pavithra et al. 2019)

Recently, nanoemulsions (NEs) also have gained a tremendous attention because of their potential in a wide variety of applications including cosmetic, food and pharmaceutical industry applications. NEs are ultrafine oil-in-water suspensions having a droplet size range of 10-600 nm (Solans et al. 2003). Previous studies reported that NEs can be used as carriers of drugs, and can impart a long shelf-life to carried drugs for antimicrobial, larvicidal, anticancer, mosquito repellent, antimicrobial and insecticidal activities (Al-Hazzani et al. 2012; Anjali et al. 2012; Pant et al. 2014; Ziani et al. 2011). Various methods were used for the formulation of NEs including high-pressure homogenization, microfluidization, spontaneous emulsification, solvent evaporation, phase inversion and ultrasonication (Date et al. 2010). Among these methods, ultrasonication is a cost-effective, easy, high energy, aseptic, fast and clean technique for NE formulation. In ultrasonic emulsification, two kinds of mechanisms are involved in the formulation of NEs. First, a combination of interfacial waves and instability generated by acoustic field leads to the 
eruption of oil phase into water medium in the form of droplets. Second, ultrasound waves of low frequency disintegrate the droplets near the interface by cavitation. The extreme instability of primary droplets produces NEs with minute droplet size (Kentish et al. 2008).

This study was aimed to evaluate the anticancer and antioxidant potential of food grade NE on primary hepatocellular carcinoma cells (HepG2). We prepared NEs from three different oils (flax seed oil, clove oil and olive oil) using Hi-Cap as an emulsifier by ultrasonication. Moreover, we used an in vitro system to evaluate antioxidant and anticancer activity of these NEs on HepG2 cancer cells.

\section{Materials And Methods}

\section{- Oil Extraction}

- Flax seed oil extraction

Oil extraction from flax seeds (acquired from botanical garden, University of the Punjab) was done by soxhlet apparatus (Sigma-Aldrich, MO, USA). $25 \mathrm{~g}$ of flax seeds was weighed and placed in a thimble. Thimble containing the sample was then placed in soxhlet extractor. Ethanol $(250 \mathrm{ml})$ was taken into three neck round bottom flask joined with extractor and flask on top along with the condenser to prevent any solvent loss. The entire apparatus was placed on water bath to achieve the required temperature. After three to four cycles, mixture of oil and solvent was separated by using rotary evaporator at $50^{\circ} \mathrm{C}$.

\section{- Clove oil extraction}

Clove buds were graciously donated by a local farmer. The sample was dried in a ventilated drying oven at $30^{\circ} \mathrm{C}$. The dried sample was grounded by the sample mill. $25 \mathrm{~g}$ of grounded sample was taken into a thimble. Thimble with sample was then inserted into a reflux flask. Ethanol $(250 \mathrm{ml})$ was used as a solvent for extraction in a soxhlet apparatus for about 6 hours. Extracts were then concentrated by using rotary evaporator at $50^{\circ} \mathrm{C}$.

\section{- Olive oil extraction}

Olive cake sample $(25 \mathrm{~g})$ and ethanol $(250 \mathrm{ml})$ was used for extraction in a soxhlet apparatus. The entire process was carried out for 6 hours. The extracted phased was then concentrated by rotary evaporator at $50^{\circ} \mathrm{C}$.

\section{- Preparation of NES}

Oil-in-water (O/W) NEs were prepared by adding oils (flaxseed, clove and olive) $5 \%$ and $10 \% \mathrm{v} / \mathrm{v}, \mathrm{Hi}-\mathrm{Cap}$ 100 (Ingredion, Hamberg, Germany) (2.5\% and $5 \% \mathrm{w} / \mathrm{v})$ in distilled water. Briefly, a coarse emulsion was prepared by homogenizing the mixture at $495 \mathrm{~g}$ for $5 \mathrm{~min}$ by using a rotor-stator homogenizer. The mixture was then sonicated by using $20 \mathrm{kHz}$ sonicator with $750 \mathrm{~W}$ power output for $1 \mathrm{~h}$ at room temperature to get fine emulsions. For generating ultrasonic waves, an ultrasound probe with tip of 13 
$\mathrm{mm}$ diameter was used. During ultrasonication, sample container was kept in an ice bath to neutralize heat energy generated during the process. The prepared NEs were analyzed for their stability, droplet size and used further for in vitro studies.

\section{- Stability of NE}

Prepared NEs were placed at $80^{\circ} \mathrm{C}$ in water bath for $30 \mathrm{~min}$ and the kept at room temperature for $15 \mathrm{~min}$. Centrifugation of NEs was done at $1300 \mathrm{~g}$ for $30 \mathrm{~min}$ at $5^{\circ} \mathrm{C}$. Phase separation, creaming, sedimentation and particle size change were checked by this method.

- Particle size determination

Formulated NEs were diluted for fifty times. After dilution, particle size distribution was done by Malvern Zetasizer Nano ZS90 (Malver Istruments, UK).

\section{- Zeta potential determination}

After diluting NEs for fifty times, zeta potential and polydispersity (PDI) was determined by Malvern Zetasizer Nano ZS90 (Malver Istruments, UK). Temperature was kept at $25^{\circ} \mathrm{C}$ and electric voltage was 3.9 V.

\section{- Antioxidant activity of NES}

- DPPH radical scavenging assay

The antioxidant activity of NEs was determined by method described by Khan et al. (2020) with modifications through 2, 2'-diphenyl-1-picrylhydrazyl (DPPH) radical scavenging activity. NEs at various concentrations $(1,10$ and $25 \mu \mathrm{l}$ ) were added into freshly prepared $5 \mathrm{ml}$ of $40 \mathrm{ppm}$ methanol solution of $\mathrm{DPPH}$, the mixture was kept in dark place for $30 \mathrm{~min}$ at $25^{\circ} \mathrm{C}$. After $30 \mathrm{~min}$ of incubation the absorbance was measured at $517 \mathrm{~nm}$ against blank for each reaction mixture. Ascorbic acid (Sigma-Aldrich, USA) was taken as positive control while DPPH solution without NEs was taken as control and methanol as blank. The reactions for all concentrations were carried out in triplicates and percentage inhibition was calculated by equation (1).

DPPH \% inhibition $=\frac{A C-A S}{A C} \times 100$.

Where, AS is the absorbance of sample and AC is the absorbance for control.

- Ferric reducing (FRAP) ability assay

The ferric ion reducing ability of the NEs was measured by a FRAP assay following the method of Shankar et al. (Shankar et al. 2016) with modifications. Briefly, NEs at various concentrations $(1,10$ and $25 \mu \mathrm{l}$ ) were added to 999,990 and $975 \mu$ respectively of FRAP reagent [250 mM sodium acetate buffer 
$(\mathrm{pH} 3.7) / 10 \mathrm{mM}$ TPTZ solution/20mM ferric chloride solution] with the ratio of 10:1:1. The mixture was then incubated for $10 \mathrm{~min}$ in the dark at $45^{\circ} \mathrm{C}$. The absorbance was measured at $593 \mathrm{~nm}$ using the spectrophotometer and the reducing activity of each sample was expressed in terms of ferrous sulfate equivalent per g FRAP.

\section{- MTT assay}

Liver cancer HepG2 cells (Nunc, Wiesbaden Germany) were seeded at the density of $1 \times 103$ cells in 96 well plate for $24 \mathrm{~h}$ at $37^{\circ} \mathrm{C}$ with $5 \% \mathrm{CO}$. Both normal and cancer cell lines were treated with different concentrations $(1,10$, and $25 \mu \mathrm{l})$ of NEs for $48 \mathrm{~h}$ incubation. After discarding old medium, $50 \mu \mathrm{l}$ of MTT supplemented media was added. After incubating for three hours at $37^{\circ} \mathrm{C}$, next refreshing step was done with $100 \mu \mathrm{L}$ dimethylsulfoxide (DMSO). After stirring for 10 minutes, the absorbance of sample was measured by a plate reader spectrophotometer at $590 \mathrm{~nm}$ in a microplate reader (Thermo Scientific, Waltham, USA). Cell viability \% was calculated by using this formula (2).

$$
\text { Cell Viability } \%=\frac{\text { Absorbance of sample }- \text { Absorbance of blank }}{\text { Absorbance of control }- \text { Absorbance of blank }}
$$

\section{- Statistical analysis}

Statistical analysis was done by one-way analysis of variance (ANOVA) to estimate the significant differences $(p<0.05)$ between mean observations by using the SPSS software (SPSS Inc., Chicago, IL, USA).

\section{Results And Discussion}

\section{- Preparation and characterization of NEs}

Oil and surfactant with different ratios were used to prepare NEs. Stable formulations were obtained at $10 \%$ oil $\mathrm{v} / \mathrm{v}$ and $5 \%$ surfactant $\mathrm{w} / \mathrm{v}$ as shown in table 1 . The most stable formulation was obtained from $10 \% \mathrm{v} / \mathrm{v}$ clove oil and $5 \% \mathrm{w} / \mathrm{v}$ Hi-Cap100 having particle size of $171.5 \pm 5.70 \mathrm{~nm}$, zeta potential of $-32.5 \pm 4.25$ and PDI of $0.396 \pm 0.01$ with 52 days of storage stability. PDI is used to measure size distribution. Lower PDI value (less than 0.1 ) indicates monodisperse size distribution while higher value $(>0.2)$ indicates heterogeneity. Lower PDI value can be correlated with more stability on storage. The surface charge of emulsion particle can be characterized by zeta-potential of emulsions.

The smaller particle size and lower zeta-potential can be due to the higher quantity of Hi-Cap 100 (5\% $\mathrm{w} / \mathrm{v}$ ) used in the formulations. NEs with high surfactant quantities have been prepared previously in literature (Sari et al. 2015). In this study, NEs prepared with clove oil showed a mean particle size below $175 \mathrm{~nm}$ due to higher amount of surfactant used which can cover droplets of oil in oil phase and thus 
reduces the interfacial surface tension as a consequence of ultrasonication through the breakdown of droplets (Jafari et al. 2008). Higher zeta potential results in improved physical stability which leads to cause repulsive forces among particles in a multiphase system. Since fatty acids are considered as the building blocks for fats, the negative charge on particle is due to the carboxylic acid group (Sood et al. 2014). Bhargava et al. (2015) prepared negatively charged oregano oil NEs with zeta-potential of -18 mV.

\section{- Antioxidant activity of NES}

The antioxidant activity was evaluated by DPPH and FRAP methodologies. The highest DPPH \% inhibition $(89 \pm 0.2 \%)$ was found for olive oil NEs at when $25 \mu \mathrm{l}$ of NEs was added into DPPH solution and absorbance was measured. Whereas lowest was observed for NEs with clove oil (78.55 $\pm 0.72 \%)$. This trend was observed for all three concentrations of NEs. The DPPH radical scavenging activity decreased in order among the NEs as olive > flaxseed > clove oil at all concentrations (Fig. 1a). The positive control ascorbic acid showed DPPH inhibition of $96.02 \pm 0.20 \%$ at $1000 \mu \mathrm{g} / \mathrm{ml}$. FRAP activity was similarly found maximum for olive oil NEs at all concentrations ranging between $495-698.5 \mu \mathrm{mol} / \mathrm{ml}$ (Fig. 1b).

Clove oil have been proven to be a potent antioxidant and showed $97.3 \%$ percentage inhibition of lipid peroxidation of linoleic acid emulsion at a concentration of $15 \mu \mathrm{g} / \mathrm{ml}$ (Gülçin et al. 2012). It has been reported in literature that flaxseed oil hull exhibited DPPH radical scavenging activity range between 49$72 \%$ depending upon the heat treatment on the oil (Herchi et al. 2016). Rebolleda et al. (2015) reported FRAP values of $471 \pm 9 \mu \mathrm{mol} \mathrm{Fe}(\mathrm{II}) / \mathrm{L}$ for wheat bran oil NEs, and compared the FRAP values for NEs and non-emulsified oil. FRAP has also been reported to react only with hydrophilic compounds in NEs

\section{- MTT assay}

NEs prepared from three samples (flax seed oil, clove oil and olive oil) were challenged against liver cancer cells (HepG2). Various concentrations of each formulated NEs $(1 \mu l, 10 \mu$ land $25 \mu$ l) were tested against control and cancer cells. The result of the NE prepared by flax seed oil, clove oil and olive oil against HepG2 cells with IC50 value were $10 \mu \mathrm{l}, 25 \mu \mathrm{l}$ and $1 \mu \mathrm{l}$ respectively (Fig. 2, 3 and 4). These results indicate the efficacy of prepared NEs by oils over application of simple oils. However, NE prepared from olive oil was reported as highly effective source against HepG2 cells with $19 \%$ viability at $25 \mu$ l.

Cancer cells were exposed to different concentrations (1-25 $\mu \mathrm{l})$ of oils and their formulated NEs to observe their inhibitory effect. Effectiveness of these oil and their prepared NEs was observed with the help of MTT assay. Results approved the anticancer effects of these oils. As a rich source of a-linolenic acid and $\omega-3$ polyunsaturated fatty acids, flax seed oil is reported to induce cancer cell death by inducing apoptosis in breast cancer and oral cancer cells (Buckner et al. 2019; Reethega and Gayathri 2018). Studies also suggest the ability of clove oil to inhibit cancer growth in thyroid cancer cells, breast cancer and prostate cancer (Rattanamaneerusmee et al. 2018). On the other hand, olive oil being the most effective to reduce HepG2 cell viability to $72 \%$ at $25 \mu$ also reported to induce cell death in other various cancer cell types (Capurso et al. 2018). However, the cell viability results indicated that formulated NEs inhibited cell growth in dose dependent manner and found more effective than their respective oils. This 
significant decline in cancer cell viability may be attributed to the capability of NE to easily invade into the cell to induce cell death (Sánchez-López et al. 2019).

\section{Conclusion}

Recently, NEs have gained tremendous attention due to their ability to make improved delivery of active pharmaceutical ingredients. The current study revealed that NEs prepared from flax seed, clove and olive oil have the potential for further development as anticancer agents.

\section{Declarations}

\section{Conflict of interest statement}

We declare that we have no conflict of interest.

\section{References}

Al-Hazzani, A., Periyasamy, V., Subash-Babu, P., \& Alshatwi, A. A., Formulation of cashew nut shell liquid (CSNL) nanoemulsion, a potent inhibitor of human MCF-7 breast cancer cell proliferation. Med Chem Res, 21(7): 1384-1388. (2012)

Anjali, C. H., Sharma, Y., Mukherjee, A., \& Chandrasekaran, N., Neem oil (Azadirachta indica) nanoemulsion-a potent larvicidal agent against Culex quinquefasciatus. Pest manag sci, 68(2): 158-163. (2012)

Bhargava, K., Conti, D. S., da Rocha, S. R., \& Zhang, Y., Application of an oregano oil nanoemulsion to the control of foodborne bacteria on fresh lettuce. Food microbiol, 47: 69-73. (2015)

Buckner, A. L., Buckner, C. A., Montaut, S., \& Lafrenie, R. M., Treatment with flaxseed oil induces apoptosis in cultured malignant cells. Heliyon, 5(8): e02251. (2019)

Capurso, A., Crepaldi, G., \& Capurso, C., Extra-virgin Olive Oil and Cancer. In Benefits of the Mediterranean Diet in the Elderly Patient (pp. 97-113). Springer, Cham. (2018)

Date, A. A., Desai, N., Dixit, R., \& Nagarsenker, M., Self-nanoemulsifying drug delivery systems: formulation insights, applications and advances. Nanomedicine, 5(10): 1595-1616. (2010)

Esmail, R. A., Mohamed, A., \& Shoreibah, E., Effect of 5-fluorouracil versus Cisplatin in combination with clove oil in management of Head and Neck Squamous cell carcinoma cell lines. Al-Azhar Dent J for Girls, 6(4): 417-426. (2019)

Gülçin, I., Elmastaş, M., \& Aboul-Enein, H. Y., Antioxidant activity of clove oil-A powerful antioxidant source. Arab J of chem, 5(4): 489-499. (2012) 
Herchi, W., AMMAR, K. B., Bouali, I., Abdallah, I. B., Guetet, A., \& Boukhchina, S., Heating effects on physicochemical characteristics and antioxidant activity of flaxseed hull oil (Linum usitatissimum $L$ ). Food Sci and Tech, 36(1): 97-102. (2016)

Jafari, S. M., Assadpoor, E., He, Y., \& Bhandari, B., Re-coalescence of emulsion droplets during high-energy emulsification. Food hydrocoll, 22(7): 1191-1202. (2008)

Javanshir, A., Karimi, E., Maragheh, A. D., \& Tabrizi, M. H., The antioxidant and anticancer potential of Ricinus communis L. essential oil nanoemulsions. J of Food Meas and Charact, 1-10. (2020)

Kentish, S., Wooster, T. J., Ashokkumar, M., Balachandran, S., Mawson, R., \& Simons, L., The use of ultrasonics for nanoemulsion preparation. Innov Food Sci \& Emerg Technol, 9(2): 170-175. (2008)

Khan, M. R., Sadiq, M. B., \& Mehmood, Z., Development of edible gelatin composite films enriched with polyphenol loaded nanoemulsions as chicken meat packaging material. CyTA-J of Food, 18(1): 137-146. (2020)

Mahato, R., Nanoemulsion as targeted drug delivery system for cancer therapeutics. J of pharmaceut sci and pharmacol, 3(2): 83-97. (2017)

Pant, M., Dubey, S., Patanjali, P. K., Naik, S. N., \& Sharma, S., Insecticidal activity of eucalyptus oil nanoemulsion with karanja and jatropha aqueous filtrates. Int. Biodeterior. Biodegradation, 91: 119-127. (2014)

Pavithra, P. S., Mehta, A., \& Verma, R. S., Essential oils: from prevention to treatment of skin cancer. Drug Discov Today, 24(2): 644-655. (2019)

Rattanamaneerusmee, A., Thirapanmethee, K., Nakamura, Y., \& Chomnawang, M. T., Differentiationinducing effect in human colon cancer cells of essential oils. Pharm Sci Asia, 45(3): 154-160. (2018)

Rebolleda, S., Sanz, M. T., Benito, J. M., Beltrán, S., Escudero, I., \& San-José, M. L. G., Formulation and characterisation of wheat bran oil-in-water nanoemulsions. Food chem, 167: 16-23. (2015)

Reethega, V., \& Gayathri, R., Cytotoxicity potential of flaxseed oil on oral cancer cell lines. Int. J of Resear in Pharmaceut Sci, 9(2). (2018)

Sánchez-López, E., Guerra, M., Dias-Ferreira, J., Lopez-Machado, A., Ettcheto, M., Cano, A., ... \& Souto, E. B., Current applications of nanoemulsions in cancer therapeutics. Nanomaterials, 9(6): 821. (2019)

Sari, T. P., Mann, B., Kumar, R., Singh, R. R. B., Sharma, R., Bhardwaj, M., \& Athira, S., Preparation and characterization of nanoemulsion encapsulating curcumin. Food Hydrocoll, 43: 540-546. (2015)

Shankar, S., Jaiswal, L., Selvakannan, P. R., Ham, K. S., \& Rhim, J. W., Gelatin-based dissolvable antibacterial films reinforced with metallic nanoparticles. RSC advances, 6(71): 67340-67352. (2016) 
Solans, C., Esquena, J., Forgiarini, A. M., Uson, N., Morales, D., Izquierdo, P., ... \& Garcia-Celma, M. J., Absorption and aggregation of surfactants in solution. Nano-emulsions: Formation, Properties and applications. Marcel Dekker, New York, 525-554. (2003)

Sood, S., Jain, K., \& Gowthamarajan, K., Optimization of curcumin nanoemulsion for intranasal delivery using design of experiment and its toxicity assessment. Colloids Surf B Biointerfaces 113: 330-7. (2014)

Ziani, K., Chang, Y., McLandsborough, L., \& McClements, D., Influence of surfactant charge on antimicrobial efficacy of surfactant-stabilized thyme oil nanoemulsions. J Agric Food Chem 59: 6247-55. (2011)

\section{Tables}

Table 1: Particle size, polydispersity index, zeta potential and stability of NEs

\begin{tabular}{|l|l|l|l|l|}
\hline Composition & $\begin{array}{l}\text { Particle size } \\
(\mathrm{nm})\end{array}$ & $\begin{array}{l}\text { Polydispersity } \\
\text { index (PDI) }\end{array}$ & $\begin{array}{l}\text { Zeta } \\
\text { potential } \\
(\mathrm{mV})\end{array}$ & $\begin{array}{l}\text { Storage } \\
\text { stability (days) }\end{array}$ \\
\hline $\begin{array}{l}\text { Flax seed oil 10\%+ Hi- } \\
\text { Cap 100 5\% }\end{array}$ & $185.3 \pm 10.28^{\mathrm{a}}$ & $0.267 \pm 0.0^{\mathrm{b}}$ & $-26.5 \pm 3.56^{\mathrm{b}}$ & $39 \pm 0^{\mathrm{b}}$ \\
\hline $\begin{array}{l}\text { Clove oil 10\% + Hi-Cap } \\
1005 \%\end{array}$ & $171.5 \pm 5.70^{\mathrm{b}}$ & $0.396 \pm 0.01^{\mathrm{a}}$ & $-32.5 \pm 4.25^{\mathrm{a}}$ & $52 \pm 2^{\mathrm{a}}$ \\
\hline $\begin{array}{l}\text { Olive oil 10\% + Hi-Cap } \\
1005 \%\end{array}$ & $175.2 \pm 14.45^{\mathrm{ab}}$ & $0.236 \pm 0.008^{\mathrm{b}}$ & $-25.3 \pm 3.50^{\mathrm{b}}$ & $30 \pm 0^{\mathrm{c}}$ \\
\hline
\end{tabular}

Different superscript letters $(a-c)$ within a column indicate $(p<0.05)$ differences among mean observations.

\section{Figures}


100

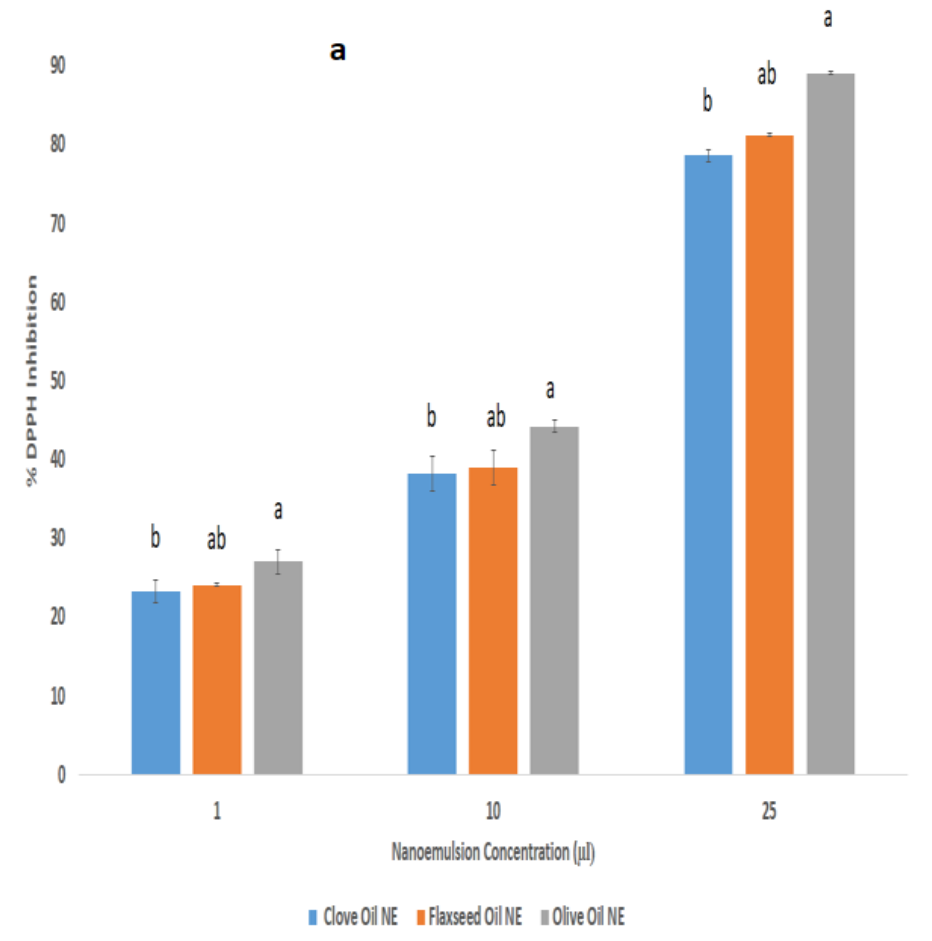

800

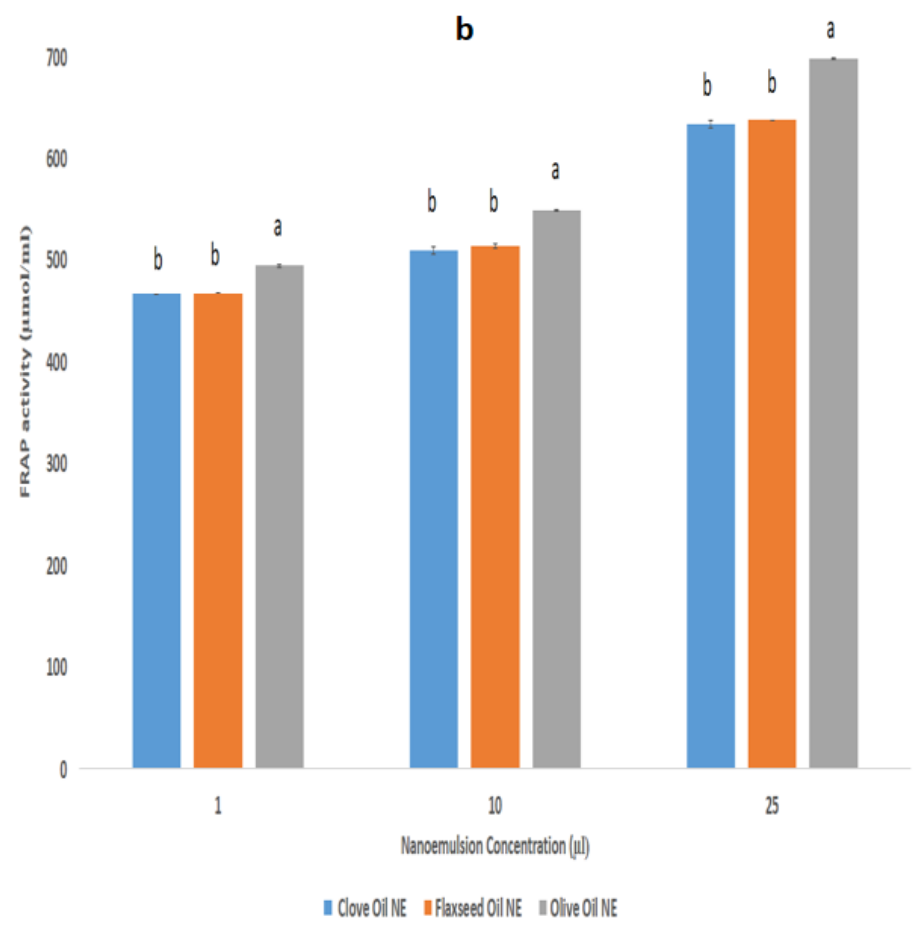

\section{Figure 1}

(a) DPPH radical scavenging activity of NEs at various concentrations. Different superscript letters (a-b) above the bars indicate significant $(p<0.05)$ differences among mean observations. (b) FRAP activity of NEs at various concentrations. Different superscript letters $(a-b)$ above the bars indicate significant $(p<$ 0.05) differences among mean observations. 


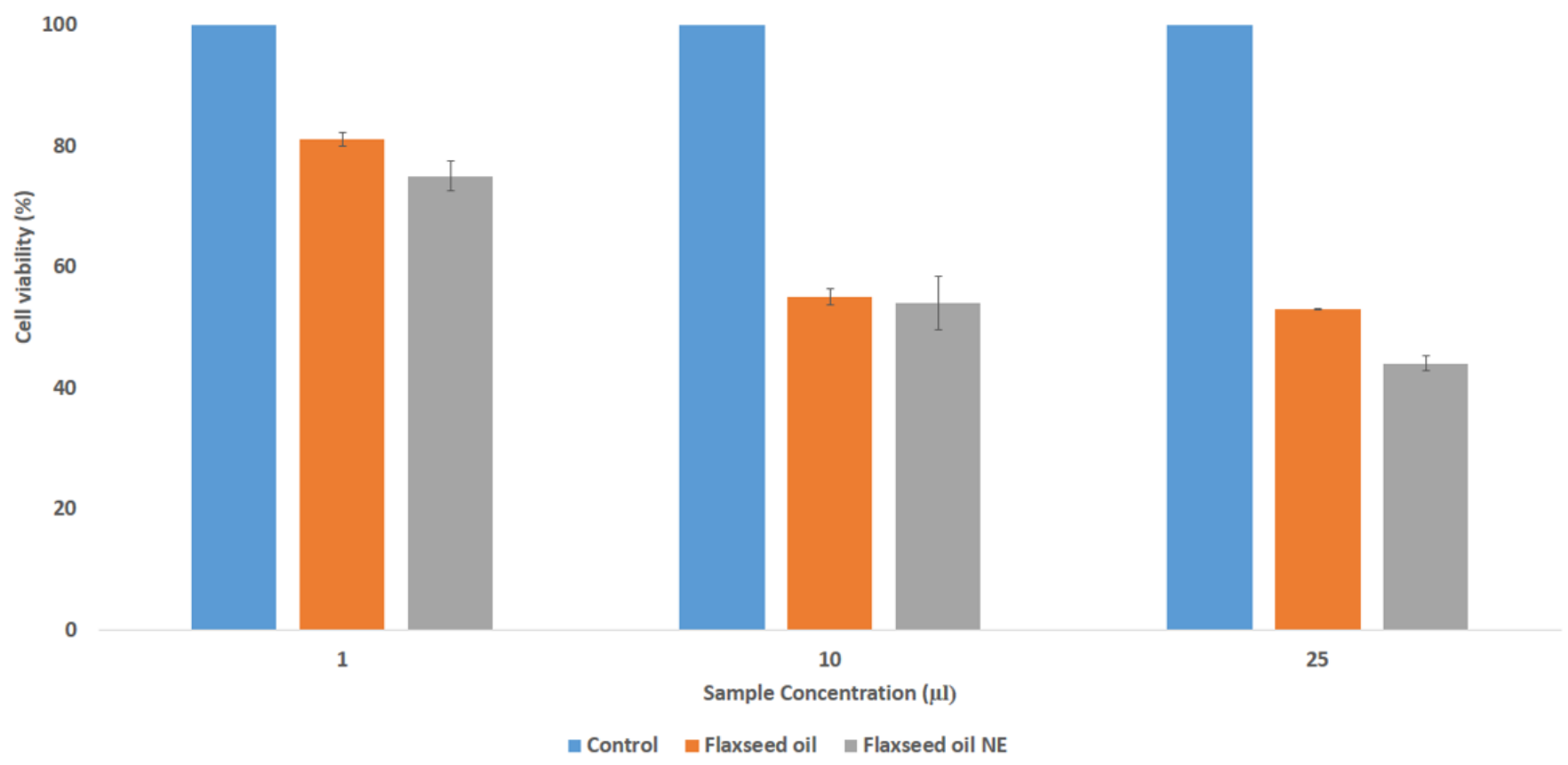

Figure 2

Anticancer activity of flax seed oil NEs

120

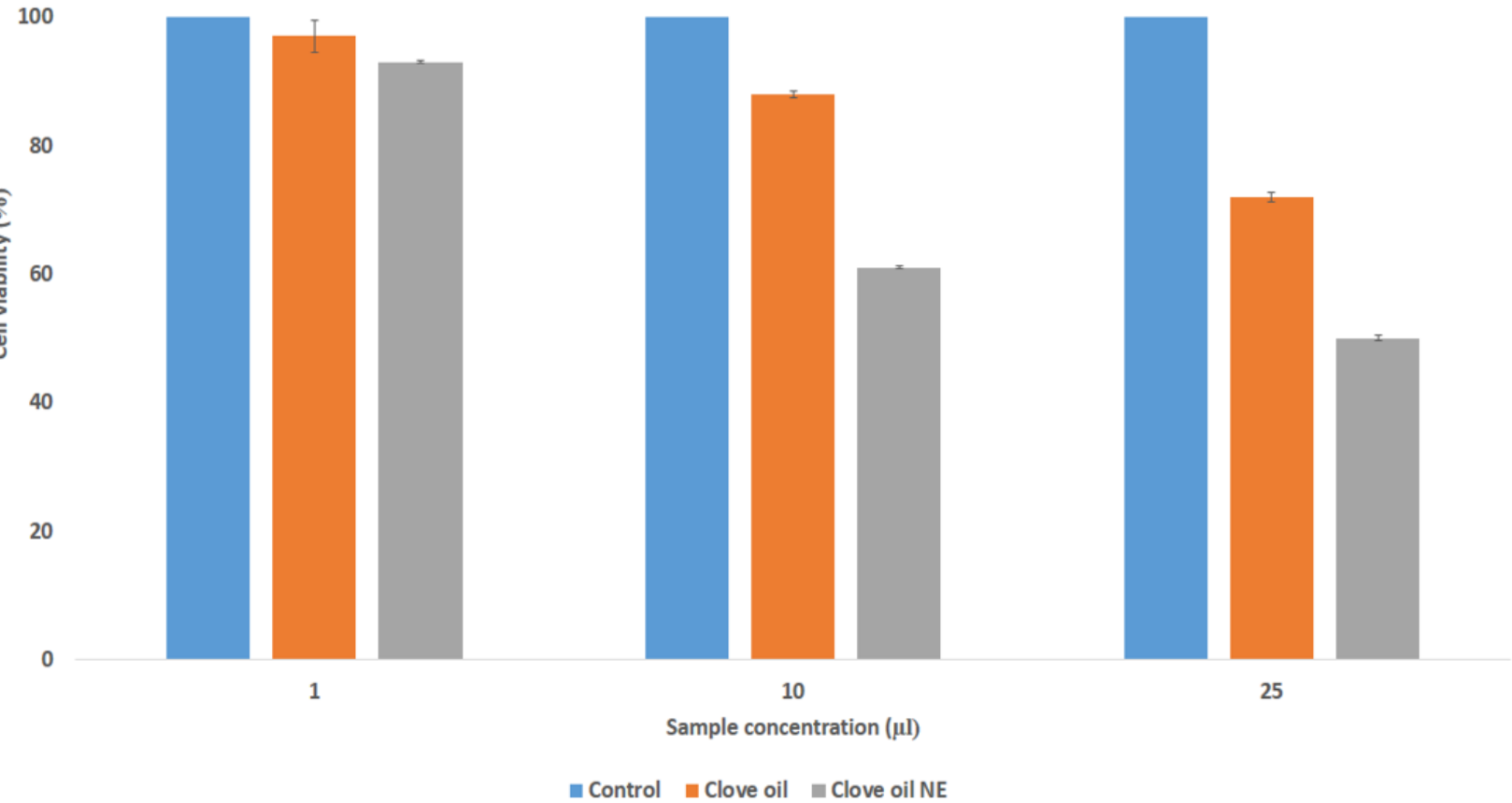


Figure 3

Anticancer activity of clove oil NEs

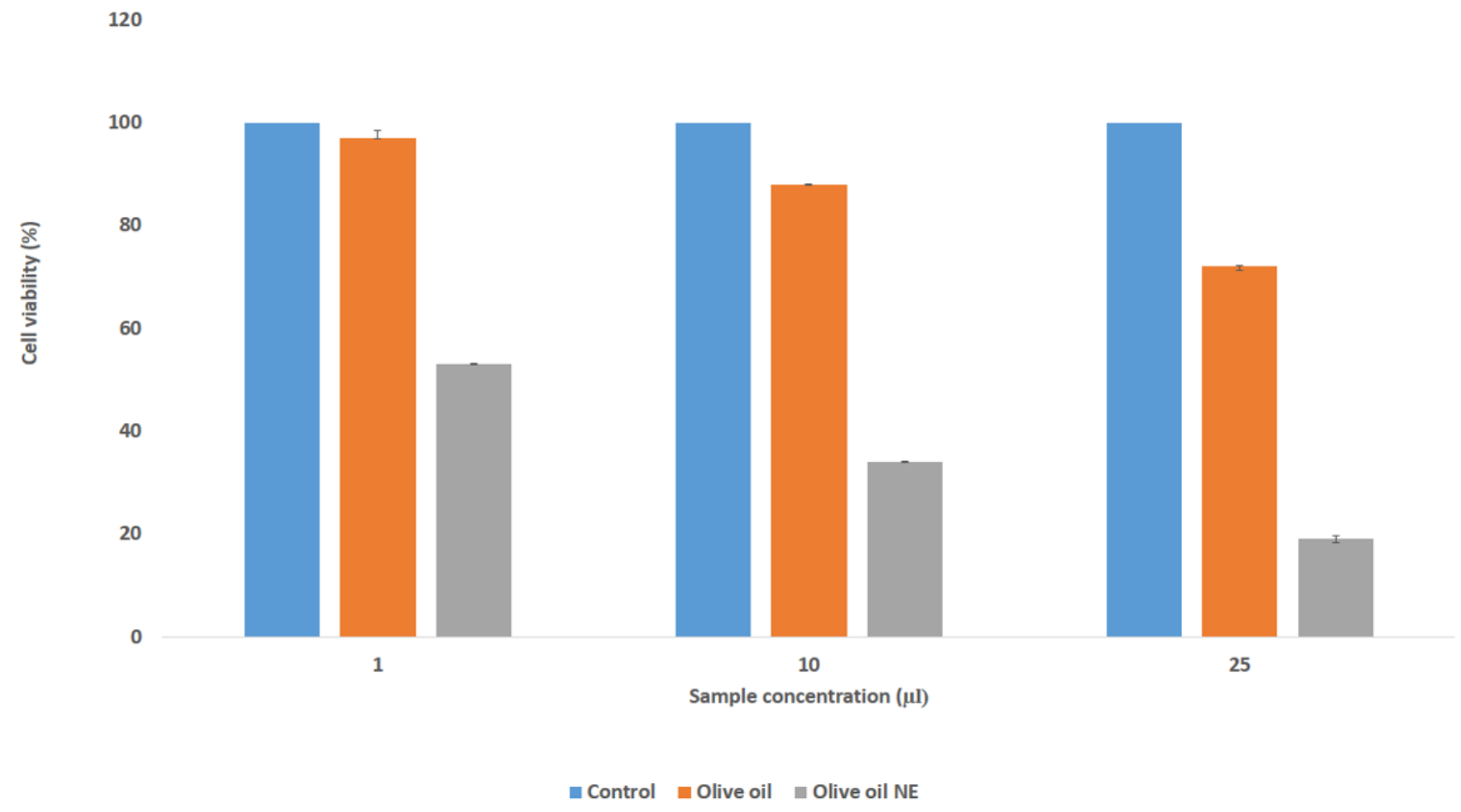

Figure 4

Anticancer activity of olive oil NEs 